\title{
Transportation Factors in the Distribution of Agricultural Produce to Urban Center in Nigeria
}

\author{
Oluwaseyi Joseph Afolabi ${ }^{1 *}$, Olalekan Adedamola Oluwaji ${ }^{1}$ and Temitayo Alice Onifade ${ }^{2}$ \\ ${ }^{1}$ Bells University of Technology, Department of Management Technology, Ota, Nigeria; Email: \\ afolabiseyo@yahoo.com,lekaniaoluwaji@gmail.com \\ ${ }^{2}$ Bells University of Technology, Department of Business Administration, Ota, Nigeria; Email: \\ Onifadeng2@yahoo.com
}

\section{${ }^{*}$ Corresponding Author: Oluwaseyi Joseph Afolabi}

\begin{abstract}
This research analyzed the transportation factors in the distribution of agricultural produce in ljebu north local government area of Ogun State. A total of 100 questionnaires were randomly and purposively distributed to transporters in Ijebu North local government Area, while 95 were collected and analyzed. The field survey revealed that 94 of the respondents representing $98.9 \%$ are male, 1 of the respondents representing $1.1 \%$ is female. Estimated income of transport operators from field survey revealed that 16 of the respondent representing $16.8 \%$ earned below N5, 000, 11 of the respondent representing $11.6 \%$ earned between N5, 001 and N10,000, 35 of the respondent representing 36.8\% earned between N10,001 and N20,000. 25(26.3\%) earn between $\mathrm{N} 20,001$ and $\mathrm{N} 30,000,8(8.4 \%)$ earn above N30,000.Observation from the field survey also shown that $5(5.3 \%)$ transporter revealed that they operate with buses, $18(18.9 \%)$ transporters revealed that they operate with station wagon, 39(41.1\%) transporters revealed that they operate with pick-up van, 20(21.1\%) transporters revealed that they operate with saloon car while $13.7 \%$ transporters revealed that they operate with other means.

Finding shows that combination of food crops, cash crops, tubers, poultry, fruits, vegetables and poultry product dominate Ijebu North Local Government Area in which farmers combined cultivation of those crops. Roads in the study area are in a deplorable condition, the type of vehicle used by farmers and traders depend on the volume of the agricultural produce.
\end{abstract}

Keywords: Agriculture, transport, farmers, rural, distribution

\section{Introduction}

As a society grows in terms of population and functions, the need for interaction among its various components also grows thereby requiring quality and effective transportation systems.

[5] had observed that, rural travel and transport in most rural areas in Nigeria still take place with great difficulties thereby compounding and worsening the problem of rural productivity and 
rural poverty. Several studies have been conducted on the nature and characteristics of rural roads which led to the problems of rural accessibility.

Agricultural produce consist of various food crops, cash crops, livestock and poultry produce as well as the perishables such as vegetables, tomatoes, pepper and fruits among others that are produced majorly in rural settlement.

The significant contribution of transport and mobility to development and the livelihoods of poor people are widely recognized. However, the development of the transport sector has become a mirage thereby undermine the role of transport in improving poor people's health. In the context of the need to step up development activity to meet the Millennium Development Goals, a better understanding of the relationship between mobility and health becomes a priority.

Transport in rural areas is generally characterized by low population density, low level of economic activities and traffic; long distances between nodal points, such as service centres; high unit costs for service delivery, operations, maintenance, and often difficult geographic and weather conditions. The relative importance of transport factors within economic development policies increases as remoteness grows. Remote areas also generally have more under-used economic resources and marginal economic activities and reorganization of economic activities in favour of remote areas could result in positive distributional benefits of economic activity [7].

\section{Literature Review}

Efficient and effective rural transportation serves as one of the channels for the collection and exchange of goods and services, movement of people, dissemination of information and the promotion of rural economy. Along this line, [15] stated that "Immobility perpetrates poverty". Effective transportation eases accessibility to inherent potentials of rural areas, which could be harnessed for the development of its economy. In other words, rural transportation provision forms an intrinsic part of rural development strategies, serving as a mechanism and catalyst for rural transformation through the reinforcement of rural development and contributes to poverty reduction by enhancing both equity and efficiency outcomes.

In Nigeria, the issue of rural transportation development has continued to be of national importance. For instance, most of the rural roads are in poor condition, and this has imposed significant cost on the national economy especially to the agricultural activities due to increased vehicle operating costs and travel times [6]. The Federal Government of Nigeria (FGN) has embarked on various programs at one time or the other to ensure the provision of adequate transport facilities to meet the needs of the rural population but these programs have not been able to achieve hundred percent success. 
In developing nation like Nigeria, problems of rural accessibility are experienced not only in terms of linkage between settlement, but also exit within the agricultural settlement as well as links roads from rural settlement to urban center in term of daily trips.

The physical condition of various rural-urban roads used in the transportation of agricultural produce in the study area is of great concern, coupled with the deplorable condition of the roads in the area. Vehicle used to transport agricultural produce along the routes linking the rural areas are rickety and unsuitable for such purpose. The major farm settlement in the area are geographically dispersed, there is need to link this settlement with the consumption center through an efficient rural-urban transport services that will bridge the gap between activity site and consumers of the agricultural produce[14].

[18], the high rate of rural-urban migration which increases urban population and unemployment, have equally aggravated crime rate in the most Nigeria urban center as major consequences of ugly trend. Able-bodied men and women are abandoning agricultural activities by migrating to cities like Lagos seeking for employment in other non-agricultural sectors. An urgent need to improve the rural-urban means of conveying agricultural produce from various producing centers to urban area to reduce poverty and hunger in the country and to meet the Millennium Development Goals [19].

The provision of infrastructure as an approach to rural development is one of the methods mostly used by developing countries of the world. The theoretical proposition of infrastructural approach to rural development be it physical, social or institutional infrastructure, is predicated on a modernization theory called the "trickle-down theory of development" [12]. According to him, this theory is a general economic development model postulated by an American economist Hirschman in 1958. This theory is of the opinion that growth is supposed to trickle down from the core to the periphery to ensure a balanced development without an area being worse-off either rural or urban. In his submission [16] stated that "growth does not appear everywhere at the same time; it manifests itself in points or poles of growth with variable intensities; it spreads by different channels and with variable terminal effects for the economy as a whole". Hence, [11] recognized a growth pole to be a point which centripetal forces are attracted and from which (in time) centrifugal forces emanates throughout the field of influence of the set of activities constituting the pole. Many regional planning scholars in regional development issues have applied this growth pole concept because the concept has a fundamental importance to contemporary regional planning and constitutes a significant percentage of regional planning activities. According to [13] one of the main advantages of this model as a tool of spatial analysis and planning of rural development relates to its total coverage of the national space economy thus embracing both urban and rural development and 
actually seeing this in an integrated way. [8] opines that growth pole as a system of spatial development within the space economy of any country will prevent parasitic development.

Rural transportation is essential not only for connecting people to jobs, health care and family in the ways that enhances their quality of life, but also for contributing to regional economic growth and development by connecting business to customers, goods to markets and tourists to destinations. Commodities including timber, fuel and agriculture product must be moved from rural areas where they are produced to urban areas where they are processed, consumed, or sent out of the state or country. Rural road network has significant effect on the distribution of facilities in rural areas and has the potential of reducing poverty [4]. Transport is life; it nurtures life and keeps life going. Transport plays a significant role in the efficient running of modern societies. It is also the engine of growth and development of societies [9].

In his contribution, [3] observes that throughout the globe, transport is basic and requirement of daily human activities. Transport makes possible movement of goods from one place to another with great ease and speed. Thus, consumers spread in different parts of the country have the benefit of consuming goods produced at distant places. Transport provides employment opportunity to individuals as drivers, conductors, pilots, cabin crew, captain of the ship, etc. who are directly engaged in transport business. It also provides employment to people indirectly in the industries producing various means of transport and other transport equipments. Nigeria vision 20:2020 document observed that an efficient transport network will allow manufacturers or producers to obtain raw material or supply national or international market at minimum cost and with minimum delay, and allow them to access the widest possible number of suppliers or workers.

Transport is a key necessity for specialization allowing production and consumption of products to occur at different locations. Transport has throughout history been a spur to expansion; better transport allows more trade and a greater spread of people. Economic growth has always been dependent on increasing the capacity and rationality of transport. Transport improvement is not always the best way to improve productivity or increase economic development.

The need for rural communities to approach development from a wider perspective has created more focus on a broad range of development goals rather than merely creating incentive for agricultural or resource based businesses. 


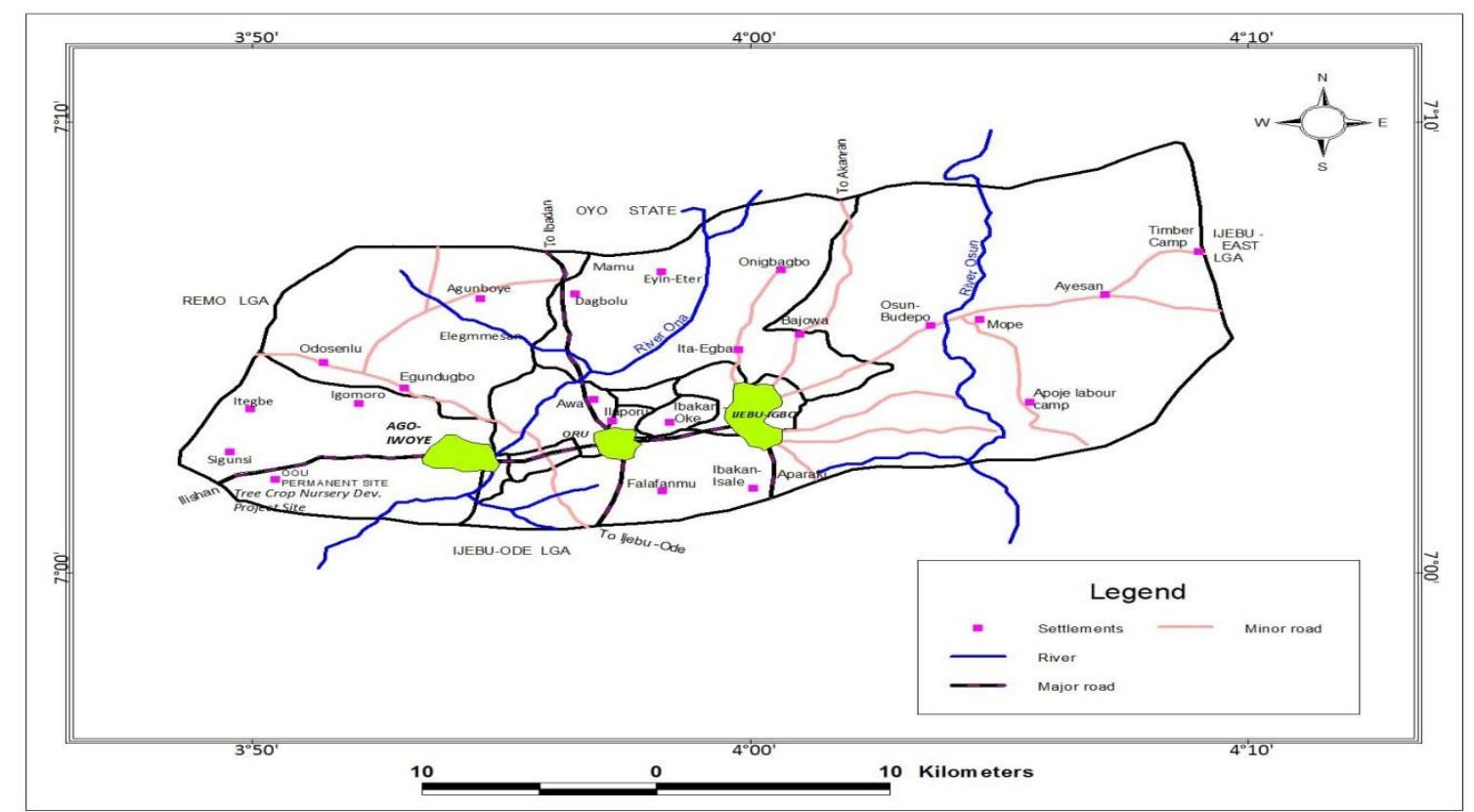

Fig. 1 Map of Ijebu North Local Government. Source: Ogun State Ministry of Lands and Housing (2017)

\section{Research Methodology}

The sources primary data for this research work consist of administration of questionnaires, oral interview and personal observation of related in the transportation of agricultural produce in the study area.

Questionnaire were randomly administered to produce transporters involving in transporting agricultural produce in the selected four (4) rural motor park (Ako-lmosu, Etiri, Dagbolu and Apoje) in the study area. This questionnaire was used to seek information on the socio-economic characteristic of the transporters, nature and type of agricultural produce, packaging and collection technique, route transportation, difficulties faced in transporting agricultural produce, how can government be of assistant and other related information on rural-urban transportation of agricultural produce in the study in particular, and the country at large.

A total of 100 questionnaires were randomly and purposively distributed to transporters in Ijebu North local government Area, while 95 were collected and analyzed.

The data collected from the questionnaire are distributed and analyzed in the tables below. 


\subsection{Socio-Economic Characteristics of the Transport Operators}

Table 1 Sex distribution of transport operators. Source: authors

\begin{tabular}{r|c|c|c|c}
\hline & Frequency & Percent & $\begin{array}{c}\text { Valid } \\
\text { Percent }\end{array}$ & $\begin{array}{c}\text { Cumulative } \\
\text { Percent }\end{array}$ \\
\hline Male & 94 & 98.9 & 98.9 & 98.9 \\
female & 1 & 1.1 & 1.1 & 100.0 \\
Total & 95 & 100.0 & 100.0 & \\
\hline
\end{tabular}

The field survey shown revealed that 94 of the respondents representing $98.9 \%$ are male, 1 of the respondents representing $1.1 \%$ is female. We can deduce that majority of the transport operators are male with a percentage of $98.9 \%$ as shown in Table 1.

Table 2 Income distribution of transport operators. Source: authors

\begin{tabular}{l|r|r|r|r}
\hline & Frequency & Percent & $\begin{array}{c}\text { Valid } \\
\text { Percent }\end{array}$ & $\begin{array}{c}\text { Cumulative } \\
\text { Percent }\end{array}$ \\
\hline below N5,000 & 16 & 16.8 & 16.8 & 16.8 \\
N5,001-10,000 & 11 & 11.6 & 11.6 & 28.4 \\
N10,001-20,000 & 35 & 36.8 & 36.8 & 65.3 \\
N20,001-N30,000 & 25 & 26.3 & 26.3 & 91.6 \\
Above N30,000 & 8 & 8.4 & 8.4 & 100.0 \\
Total & 95 & 100.0 & 100.0 & \\
\hline
\end{tabular}

Estimated income of transport operators from field survey revealed that 16 of the respondent representing $16.8 \%$ earned below N5, 000, 11 of the respondent representing $11.6 \%$ earned between $\mathrm{N} 5,001$ and N10,000, 35 of the respondent representing 36.8\% earned between N10,001 and $\mathrm{N} 20,000.25(26.3 \%)$ earn between N20,001 and N30,000, 8(8.4\%) earn above N30,000.

Table 3 Route of operation. Source: authors

\begin{tabular}{l|r|r|r|r}
\hline & Frequency & Percent & \multicolumn{1}{c|}{$\begin{array}{c}\text { Valid } \\
\text { Percent }\end{array}$} & $\begin{array}{c}\text { Cumulative } \\
\text { Percent }\end{array}$ \\
\hline ago-iwoye-mamu & 14 & 14.7 & 14.7 & 14.7 \\
area & 26 & 27.4 & 27.4 & 42.1 \\
ago-iwoye-ako area & 21 & 22.1 & 22.1 & 64.2 \\
ijebu-igbo-ome area & 25 & 26.3 & 26.3 & 90.5 \\
ijebu-igbo-osun area & 9 & 9.5 & 9.5 & 100.0 \\
Others & 95 & 100.0 & 100.0 & \\
Total &
\end{tabular}


The field survey shown that 14 (14.7\%) transporters operate along Ago lwoye- Mamu route, 26 (27.4\%) transporters operate along Ago lwoye-Ako route, 21(22.1\%) transporters operate along ljebulgbo-Ome route, 25(26.3\%) transporters operate along ljebulgbo-Osun route while 7( 9.5)\% transporters operate along other route.

Table 4 Type of Vehicle used by transporters. Source: authors

\begin{tabular}{l|r|r|r|r}
\hline & Frequency & Percent & $\begin{array}{c}\text { Valid } \\
\text { Percent }\end{array}$ & Cumulative Percent \\
\hline Bus & 5 & 5.3 & 5.3 & 5.3 \\
station & 18 & 18.9 & 18.9 & 24.2 \\
wagon & 39 & 41.1 & 21.1 & 45.3 \\
pick up van & 20 & 21.1 & 41.1 & 86.3 \\
saloon car & 13 & 13.7 & 13.7 & 100.0 \\
Others & 95 & 100.0 & 100.0 & \\
Total &
\end{tabular}

Observation from the field survey shown that 5(5.3\%) transporter revealed that they operate with buses, 18(18.9\%) transporters revealed that they operate with station wagon, 39(41.1\%) transporters revealed that they operate with pick-up van, 20(21.1\%) transporters revealed that they operate with saloon car while $13.7 \%$ transporters revealed that they operate with other means. Majority of the respondents operate with pick-up van with a percentage of $41.1 \%$ as shown in Table 4 above.

Table 5 Operating cost for Transporters. Source: authors

\begin{tabular}{l|r|r|r|r}
\hline & Frequency & Percent & $\begin{array}{c}\text { Valid } \\
\text { Percent }\end{array}$ & $\begin{array}{c}\text { Cumulative } \\
\text { Percent }\end{array}$ \\
\hline Petrol & 22 & 23.2 & 23.2 & 23.2 \\
Maintenance & 42 & 44.2 & 44.2 & 67.4 \\
Ticketing & 9 & 9.5 & 9.5 & 76.8 \\
Extortion & 21 & 22.1 & 22.1 & 98.9 \\
Others & 1 & 1.1 & 1.1 & 100.0 \\
Total & 95 & 100.0 & 100.0 & \\
\hline
\end{tabular}

Produce transporters were ask about their operating cost of the transport in the study area which revealed that 22 of the respondent representing $23.2 \%$ opined petrol is an operating cost, 42 of the respondent representing $44.2 \%$ indicate that maintenance is an operating cost, 9 of the respondent representing $9.5 \%$ indicate that ticketing is an operating cost, 21(22.1) said extortion, while 1(1.1) 
said they had other operating costs. We can deduce that most of the transport operators find maintenance as the greatest operating cost with a percentage of $44.2 \%$ as shown in Table 5 above.

Table 6 Problem facing transport operators. Source: authors

\begin{tabular}{l|r|r|r|r}
\hline & Frequency & Percent & $\begin{array}{c}\text { Valid } \\
\text { Percent }\end{array}$ & $\begin{array}{c}\text { Cumulative } \\
\text { Percent }\end{array}$ \\
\hline Extortion & 3 & 3.2 & 3.2 & 3.2 \\
restriction of routes & 21 & 22.1 & 22.1 & 25.3 \\
bad roads & 66 & 69.5 & 69.5 & 94.7 \\
Others & 5 & 5.3 & 5.3 & 100.0 \\
Total & 95 & 100.0 & 100.0 & \\
\hline
\end{tabular}

According to the field survey the challenges facing the transport operators in the study area revealed that 3 of the respondent representing 3.2\% opined that extortion is a problem facing them, 21 of the respondent representing $22.1 \%$ indicate that restriction of routes is the problem, 66 of the respondent representing $69.5 \%$ indicate that bad roads the problem facing them while 5(5.3) said they had other problems. We can deduce that most of the transport operators find bad roads the greatest problem with a percentage of $69.5 \%$ as shown in Table 6 above.

Table 7 Transporters suggestion for improved produce transportation. Source: authors

\begin{tabular}{l|r|r|r|r}
\hline & Frequency & Percent & \multicolumn{1}{|c|}{$\begin{array}{c}\text { Valid } \\
\text { Percent }\end{array}$} & $\begin{array}{c}\text { Cumulative } \\
\text { Percent }\end{array}$ \\
\hline $\begin{array}{l}\text { provision of more } \\
\text { vehicles } \\
\text { massive road } \\
\text { rehabilitation } \\
\text { minimization of } \\
\text { extortion }\end{array}$ & 8 & 8.4 & 8.4 & 8.4 \\
Total & 85 & 89.5 & 89.5 & 97.9 \\
\hline
\end{tabular}

The survey carried out revealed that 8 of the respondent representing $8.4 \%$ suggested provision of more vehicle, 85 of the respondent representing $89.5 \%$ suggested massive road rehabilitation in the study area while 2 of the respondent representing $2.1 \%$ suggested minimization of law enforcement agency. The studies revealed that majority of the transporters are of the opinion that massive road rehabilitation will improved produce transportation in the study area. 


\section{Conclusion}

The use of transportation in any human society cannot be over emphasized because; it is regarded as the only means of movement from one place to the other. In the world today, poverty reduction in the rural area is tied to rural-urban transport and it remains the central goal of global development effort. A greater percentage of the Nigerians population lives in the rural area and they are mostly farmers, they engage in the production of agricultural produce consumed in the cities and most of the agricultural materials used by the industries [2].

In other words, without further development of rural areas, it is unlikely that Nigeria will be able to feed its people, develop more agricultural industries, provide adequate employment or sustain current levels of foreign exchange earnings from export at the time when the price of crude oil falling drastically at the international market. However, the transports needed to evacuate agricultural produce from the rural area are not available or inadequate, road transport covers the widest network in the country, it is easy to expand and it provides the most flexible services [10].

\section{References}

[1] Adedeji, O.A. et al (2014). An Assessment of impact of the Impact of Road Transport on Rural Development, A case study of Obokun Local Government Area of Osun State, Nigeria. British Journal of Environmental Sciences, 29(1), 34-48.

[2] Adeniji, A. (1999). Transport of Subsidies in Nigeria; A Synopsis of Workshop Proceedings, Nigeria Institute of Social and Economic Research, Ibadan.

[3] Ademiluyi, I.A. (2006). Historical Evolution and characteristics of Transport Modes in Nigeria, Babcock journal of Management and Social Sciences, 5(1), 91-109.

[4] Aderamo, A.J. \& Magaji, S.A. (2010). Rural Transportation and the Distribution of Public Facilities in Nigeria: A Case of Edu Local Government Area of Kwara State. Journal of Human Ecology, 29, 171-179. Kamla-Raj Publishers.

[5] Adesanya, A. (2000). Transportation Development in Nigeria in 2010 Ibadan: Nigerian Institute of Social and Economic Research (NISER).

[6] Akintola, S.R. (2007). Coping with infrastructural deprivation through collective actionamong rural people in Nigeria. Nomadic Journal of African Studies, 16, 30- 46.

[7] Aloba, O. (1983). Evolution of rural roads in the Nigeria Cocoa Belt. Journal of Tropical Geography, 4, 1-10. 
[8] Ayeni, B. (1980). Models of integrated rural development: Facts and fallacies. Paper presented at the Conference on Integrated Rural Development and Women in Development, University of Benin.

[9] Badejo, B.A. (2011). Transportation: Removing the Clog to Nigeria Development, Lagos.

[10] Filani, M.O. (1993) Transport and Rural Development in Nigeria. Journal of Transport Geography.

[11] Obateru, O.I. (2005). Planning regional and rural development. Penthouse Publication, Ibadan, Nigeria. Chapter 9.

[12] Oguzor, N.S. (2011). A spatial analysis of infrastructures and social services in rural Nigeria. Geo Tropico, 5(1).

[13] Okafor, F.C. \& Onokerhoraye, A.G. (1986). Rural systems and planning, The Geography and Planning Series of Study Notes. Benin, Eguavoen Printers. Nigeria

[14] Olayiwola, L.M. \& Adeleye, O.A. (2005). Rural infrastructural development in Nigeria between 1960-1990- Problems and challenges. Journal of Social Science, 11, 91-96.

[15] Owen, K. (2008). Strategies for mobility. Washington. The Brockiling Institute.

[16] Perroux, F. (1955). Note sur la notion de pole de croissance, Economie appliquee, p. 94 after Cambell J., A note on growth poles, Growth and Change, 5(2), April 1974, p. 43.

[17] Ratcliffe, J. (1985). An Introduction to Town and Country Planning, London, Hutchinson \& Co. Publishers.

[18] Taiwo, K.A. (2009). The Global food Crisis and the African Women Farmers. In proceeding of $3^{\text {rd }}$ International Conference of west African Society of Agricultural Engineers and $9^{\text {th }}$ International Conference of Nigeria Institute of Agricultural Engineers held at Obafemi Awolowo University, January 25-29 (pp. 307-318). Ile Ife, Nigeria.

[19] UNDP (2010): Fast Facts on the MDGs, online version accessed at www.undp.org.mdg. 